doi:10.4149/neo_2015_061

\title{
RAGE and its ligands in cancer - culprits, biomarkers, or therapeutic targets?
}

\section{Minireview}

P. TESAROVA ${ }^{1, *}$, M. CABINAKOVA ${ }^{1}$, V. MIKULOVA ${ }^{2}$, T. ZIMA², M. KALOUSOVA ${ }^{2}$

${ }^{1}$ Department of Oncology, 1st Faculty of Medicine, Charles University and General University Hospital, Prague, Czech Republic; ${ }^{2}$ Institute of Medical Biochemistry and Laboratory Diagnostics, 1st Faculty of Medicine, Charles University and General University Hospital, Prague, Czech Republic

*Correspondence: tesarova.petra@seznam.cz

Received September 27, 2014 / Accepted March 2, 2015

\begin{abstract}
Receptor for advanced glycation end products (RAGE) plays a central role in the regulation of tissue homeostasis, regeneration and resolution of inflammation, but under pathological conditions RAGE-mediated pathways may induce diminished apoptosis, but enhanced autophagy and cell necrosis. These mechanisms may contribute to malignant transformation, cancer progression and metastases. Soluble RAGE may bind natural RAGE ligands and counteract some of the RAGE-mediated effects. Activation of RAGE was demonstrated in different types of cancer (including colon, pancreatic and breast cancer). Expression of RAGE and serum levels of soluble RAGE may serve as cancer biomarkers and strategies aimed at interfering with RAGE signaling might be promising anticancer drugs.
\end{abstract}

Key words: RAGE, cancer, HMGB1, S100 proteins

\section{Receptor for advanced glycation products (RAGE)}

Innate immunity plays an important role not only in the defense of organisms against external pathogens, but also in the reaction to the dying and modified cells, e.g. in cancer.

Cells involved in the innate system detect either pathogen-associated molecular patterns (PAMP) or endogenous molecules released due to the tissue injury or inflammation - danger-associated molecular patterns (DAMP). Toll-like receptors (TLR) were the first being characterized as so called pattern-recognition receptors (PRR), which act as immune sensors that discriminate self from non-self and link innate to adaptive immunity [1]. PRR were shown to be involved in microbe internalization by phagocytes (soluble PRR and endocytic receptors) and/or cell activation (signaling PRR). Classes of PRRs that have been recently discovered include RIG-I-like receptors, Nod-like receptors, and C-type lectin receptors [2].
PRR recognize also dying or damaged cells (i.e. self modified). Apoptotic cell recognition involves soluble bridging molecules (e.g. pentraxins) and endocytic receptors (e.g. scavenger receptors, the CD91-calreticulin complex). Apoptotic cells induce an immunosuppressive signal, avoiding the initiation of an autoimmune response. By contrast, necrotic cells, via the release of damage (or danger)-associated molecular patterns (DAMP) activate innate immunity and induce subsequent inflammation [3]. The prototypic DAMP is the high mobility group box 1 (HMGB1), a DNA-binding nuclear protein released from the cells either passively during cell death, or actively upon cytokine stimulation. HMGB1 may associate with Toll-like receptor (TLR) ligands and activate cells through TLR2 and TLR4, but it can also directly activate cells through multiligand receptor called RAGE (receptor for advanced glycation end-products).

Whereas TLR are involved namely in detecting PAMP with the established role in the host immune response to infection, 
receptor for advanced glycation products (RAGE) is a PRR involved in recognizing endogenous molecules associated with the tissue damage (DAMP) [4]. RAGE and TLRs may share some ligands (e.g. HMGB1, S100A8/A9 and LPS) and also singaling pathways and may cooperate in the innate immune response $[5,6]$.

RAGE is an evolutionarily recent single transmembrane member of the immunoglobulin superfamily, encoded in the class III region of the major histocompatibility complex on the chromosome 6 [7]. RAGE may be bound by many ligands which include advanced glycation endproducts, certain members of the S100/calgranulin family, extracellular HMGB1 -amphoterin, the integrin Mac-1, amyloid beta-peptide and fibrils (Table 1) $[4,8]$. Serving as counter-receptor for leukocyte integrins ( $\beta-2$ integrins) RAGE may also play an important role in cell adhesion and clustering as well as recruitment of inflammatory cells [9]. Another important ligand for RAGE may be glycosaminoglycans (including chondroitin sulfate, dermatan sulfate and heparan sulfate) which are frequently attached to proteoglycans at the surface of cancer cells and may play an important role in the malignant transformation of the tumor and metastasis [10]. Lysophosphatidic acid regulates proliferation, survival, motility and invasion of cells. Lysophosphatidic acid avidly binds to RAGE and RAGE is required for its signaling [11], phosphorylation of Akt and cyclin D which may thus also result in promoting carcinogenesis. Although these ligands are chemically very different they all share negative charges on their surface and they have a tendency to oligomerize [4].

RAGE is constitutively highly expressed only in the lung at readily measurable levels, but increases quickly at sites of acute or chronic inflammation, largely on inflammatory and epithelial cells [8].

RAGE may occur either as a membrane-bound or soluble protein that is markedly upregulated by stress in epithelial cells, thereby regulating their metabolism and enhancing their central barrier functionality. Activation and upregulation of RAGE by its ligands generally leads to enhanced survival of the RAGE expressing cells. RAGE and its soluble forms thus play a key role in the regulation of metabolism, inflammation and the survival of epithelial cells [7].

\section{Mechanisms of signalling upon RAGE activation}

Activation of RAGE by its ligands stimulates diverse signaling cascades. Upon RAGE ligation, adaptor proteins (i.e., diaphanous-1, TIRAP, MyD88 and/or other as yet unidentified adaptors) associate with RAGE cytoplasmic domain resulting in signaling.

Cytoplasmic domain of RAGE interacts with diaphanous or mDia-1 which links RAGE signal transduction to cellular migration and activation of the Rho GTPases, cdc42 and rac-1 [12]. Other cascades activated upon RAGE signaling are inflammation (NFKB, NFAT1) [13] and proliferation (MAPK - mediated by p21 Ras and JAK/STAT ) [14] stimulating pathways. Following activation of RAGE by lysophosphatidic acid (LPA - fundamental in cellular processes such as proliferation, survival, motility, and invasion implicated in many homeostatic and pathological conditions) autotaxin/ LPA-driven phosphorylation of Akt and cyclin D1 results in proliferation and migration of the cells [11]. Activation of RAGE splice variant (RAGEv1 - vide infra) may, on the other

Table 1. Multiple ligands of RAGE

\begin{tabular}{lll}
\hline Ligand & Binding & Potential role \\
\hline Advanced glycation endproducts (AGEs) & $\begin{array}{l}\text { Heterogeneous group of molecules derived from } \\
\text { glycation of proteins, high-affinity binding }\end{array}$ & $\begin{array}{l}\text { Diabetic complications, including diabetic } \\
\text { nephropathy, accelerated atherosclerosis and } \\
\text { cardiovascular disorders, chronic inflammatory } \\
\text { diseases, cancer (kidney, prostate) }\end{array}$ \\
\hline $\begin{array}{lll}\text { S100 proteins: S100B, S100P, S100A1, S100A2, } \\
\text { S100A4. S100A5, S100A6, S100A8/A9, } \\
\text { S100A12, S100A13 }\end{array}$ & $\begin{array}{l}\text { Large group of small calcium-binding proteins, } \\
\text { not all of them demonstrated to bind RAGE (e.g. } \\
\text { S100A5) }\end{array}$ & $\begin{array}{l}\text { Inflammation, neurodegeneration, differentiation } \\
\text { and cell growth, including cancer }\end{array}$ \\
\hline High-mobility group box-1 protein (HMGB1) & $\begin{array}{l}\text { Nuclear DNA-binding protein, extracellular } \\
\text { HMGB1 binds to both RAGE and TLR }\end{array}$ & Inflammation, cancer \\
\hline Amyloid $\beta$ and amyloid fibrils & $\begin{array}{l}\text { Form insoluble extracellular aggregates, putative } \\
\text { role of RAGE in transportation of amyloid } \\
\beta \text { across blood-brain barrier }\end{array}$ & Alzheimer disease \\
\hline$\beta-2$ integrin Mac-1 & $\begin{array}{l}\text { Surface receptor (CD11b/CD18) involved in } \\
\text { leukocyte adhesion and migration (possibly } \\
\text { augmented by S100B, S100A9, HMGB1) }\end{array}$ & Inflammation \\
& $\begin{array}{l}\text { Attached to proteoglycans at the surface cells } \\
\text { (including cancer cells) }\end{array}$ & Malignant transformation, metastasis \\
\hline $\begin{array}{l}\text { Glycosaminoglycans (including chondroitin } \\
\text { sulfate, dermatan sulfate and heparan sulfate) }\end{array}$ & $\begin{array}{l}\text { RAGE required for lysophosphatidic acid signaling } \\
\text { Lysophosphatidic acid }\end{array}$ & $\begin{array}{l}\text { Regulation of proliferation, survival, motility and } \\
\text { invasion of (cancer) cells }\end{array}$ \\
\hline
\end{tabular}


hand, suppress c-jun-NH(2)-kinase (JNK) pathway signaling [15] suggesting that activation of RAGE may promote both proliferative and antiproliferative responses based on the splice variant of RAGE expressed.

\section{Activation of RAGE in health and disease}

However, RAGE activation may not be restricted only to the pathological situations, the receptor being involved in tissue homeostasis and regeneration repair upon acute injury, and in resolution of inflammation. RAGE effects are strongly dependent on the cell type and the context, which may be kept in mind when any therapeutic strategies aimed at reducing RAGE signaling are considered.

Perpetual signaling through RAGE-induced survival pathways in the setting of limited nutrients or oxygenation results in enhanced autophagy, diminished apoptosis, and (with ATP depletion) necrosis [7]. Engagement of RAGE results in sustained NF- $\mathrm{kB}$ activation and converts a short cellular activation to persistent cellular dysfunction and tissue destruction [16]. This results in chronic inflammation and may enhance malignant transformation of epithelial cells. RAGE may thus be involved in cancerogenesis and cancer progression [8].

As a multiligand receptor of enviromental stressors RAGE upregulation has been implicated in aging and many pathological processes, including immune/inflammatory disorders, diabetes and its complications, including diabetic nephropathy, atherosclerosis, neurodegeneration and Alzheimer's diseas and also tumorigenesis, and metastasis [12, $17-19]$.

\section{Soluble RAGE}

Circulating soluble forms of RAGE (sRAGE) may arise either from receptor ectodomain shedding (this form is sometimes called cleaved RAGE), or splice variant [endogenous secretory (es) RAGE] secretion and may counteract RAGEmediated cellular effects by acting as a decoy [20]. sRAGE thus represents a naturally occurring competitive inhibitor of RAGE-mediated events.

Besides the full-length RAGE protein in humans nearly 20 natural occurring RAGE splicing variants were described on mRNA and protein level $[14,18]$. These naturally occurring isoforms are characterized by either $\mathrm{N}$-terminally or C-terminally truncations, including a soluble form called endogenous secretory RAGE (esRAGE) which may function as possible regulators of the full-length RAGE receptor either by competitive ligand binding or by displacing the full-length protein in the membrane. RAGE has several isoforms derived from alternative splicing. Analysis of splice variants for premature termination codons reveals that approximately $50 \%$ of identified variants are targeted to the nonsense-mediated mRNA decay pathway. Expression analysis demonstrated that the RAGE_v1 variant is the primary secreted soluble isoform of RAGE [17].
Cells may produce also a form of soluble RAGE, derived from proteolytic cleavage of the membrane-bound molecules by the sheddase ADAM10, a membrane protease responsible for RAGE cleavage (cleaved soluble RAGE). Binding of HMGB1 to RAGE promotes RAGE shedding.

Soluble forms of RAGE (sRAGE), including the splice variant endogenous secretory (es)RAGE, have been found circulating in plasma and tissues [21]. Both sRAGE and esRAGE may serve as biomarkers or endogenous protection factors against RAGE-mediated pathogenesis. Deregulations of the circulating levels of soluble RAGE forms were reported in several RAGE-associated pathological disorders including, for example atherosclerosis, diabetes, renal failure, Alzheimer's disease, and several cancer types. Monitoring of plasma sRAGE levels could thus provide help to assess the severity of the inflammatory, or cancer disease and the response of the disease to the therapeutic intervention. sRAGE could also serve as a predictor of the outcome. Pharmacological blockade of RAGE or genetic deletion of RAGE was shown to impart a significant protection in murine models of diabetes, inflammatory conditions, Alzheimer's disease, and some tumors.

\section{RAGE expression in cancer}

Receptor for advanced glycation end products (RAGE) and its ligands are overexpressed in multiple cancers [15]. On the other hand, there are apparent differences between RAGE expression in different tumors. RAGE was found to be highly expressed in hepatocellular, colorectal, and breast cribriform carcinomas, but not at all in malignant testicular specimens [22]. On the oppposite, RAGE expression is decreased in lung cancer.

RAGE has been implicated in tumorigenesis, cancer growth and metastasis [23], but relatively little is known of the mechanisms involved, but both cancer-induced carbonyl stress (increased production of AGEs) and tissue hypoxia with the release of DAMP may be involved. Moreover, activation of RAGE elicits oxidative stress generation and evokes inflammatory and thrombogenic responses which may contribute to the progression of cancer and development of some of its complications.

Cancer is associated with increased glycolysis and carbonyl stress [24]. In view of this, AGE modified proteins were, e.g. identified from clinical breast cancer tissue using $2 \mathrm{DE}-$ immunoblot and mass-spectrometry. These proteins were identified to be transferrin, fibrinogen gamma chain, glycerol3 -phosphate dehydrogenase, lactate dehydrogenase, annexin II, prohibitin and peroxiredoxin 6, which all have established role in cancer. Further, RAGE expression correlated with AGE levels and NOX2 and NF-kappa B expression [23].

Hypoxia which may play a role in tumor progression was shown to increase expression of the receptor for advanced glycation end products (RAGE) [25]. Hypoxic tumor cells treated with HMGB1 activate Akt and Erk phosphorylation 
resulting in the nuclear accumulation of NF- $\mathrm{kB}$ and increased cell invasion. Inhibition of Akt and Erk and silencing RAGE prevented or abolished both nuclear translocation of NF- $\mathrm{kB}$ and cell invasion. Hypoxia induced release of HMGB1 from necrotic cells and increased expression of RAGE.

\section{Role of RAGE expression and RAGE polymorphisms in different types of cancer (table 2)}

RAGE expression and RAGE polymorphisms were studied in different types of cancer. Most frequently studied polymorphisms of RAGE are: rs1800625 (-429T/C), rs1800624 (-374T/A), rs3134940 (2184A/G) and rs2070600 (557G/A, also frequently named Gly82Ser). Ethnicity may play an important role in the occurrence of some polymorphisms, e.g. most studies relating cancer susceptibility to Gly82Ser polymorphisms comes from China and this type of polymorphism is relatively rate in Caucasian patients. Interestingly Gly82Ser polymorphism may be related to RAGE glycosylation and ligand binding $[26,27]$.

RAGE is abundant in both the transcriptional and translational level in normal lung but is not expressed in non-small cell lung cancer (NSCLC) [28]. Using immunohistochemisty membranous and cytoplasmic RAGE was less expressed in lung cancer tissue than in nearby normal lung tissue $[29,30]$. RAGE overexpression in lung alveolar type I epithelial cells was downregulated upon malignant transformation and this downregulation was associated with increased aggressiveness of malignant cells [31].

RAGE apparently plays an important role in normal lung physiology, possibly stabilizing mature alveolar epithelial cells as an adhesion molecule. Downregulation of RAGE observed in lung cancer may then interrupt cell-cell and cell-substrate communication and thus enhances tumor growth and migration of cancer cells.

In another paper three major RAGE genetic polymorphisms, namely, $-429 \mathrm{~T} / \mathrm{C},-374 \mathrm{~T} / \mathrm{A}$ and $82 \mathrm{G} / \mathrm{S}$ were found to be associated with susceptibility for non-small cell lung cancer (NSCLC) [32]. Only the 82G/S polymorphisms denoted, however, a significant difference between responders and non-responders to chemotherapy. The 82SS genotype and $82 \mathrm{~S}$ allele distribution not only increased the NSCLC risk, but also was associated with a lower platinum-based chemotherapy response rate and poor prognosis, indicated by overall survival and progression free survival. In a large study in Han Chinese [33] two out of three tested RAGE gene polymorphisms (rs1800625, rs2070600) occurred more frequently among lung cancer patients suggesting that RAGE may contribute to the pathogenesis of lung cancer among Han Chinese.

Expression of mRNA for RAGE and its splice variants was shown to be increased in esophageal cancer [29].

A Gly82Ser polymorphism in exon 3 of RAGE gene was also studied in patients with gastric cancer [34]. The dis- tribution of genotype was significantly different between cases and controls. Compared with the wild-type $82 \mathrm{Gly} / \mathrm{Gly}$ carriers, subjects with the variant genotypes (82Gly/Ser and $82 \mathrm{Ser} / \mathrm{Ser}$ ) had a significantly higher risk of gastric cancer $(\mathrm{HR}=1.47)$. Risk of gastric cancer was elevated especially in younger individuals (aged $\leq 58$ years), nonsmokers, and rural subjects and variant genotypes were also associated with cancer invasion.

RAGE was found to be highly expressed in colorectal cancer [22] and high expression of RAGE in primary tumor correlated with the formation of metastases and reduced survival [35].

In a recent Chinese study Gly82Ser RAGE polymorphism was shown to be associated with increased risk of colorectal cancer [36]. Gly82Ser polymorphism was also more frequent in patients with advanced colorectal cancer (TNM III + IV) and patients with poorly differentiated colorectal cancer, suggesting that in Chinese population this polymorphism may be associated not only with the increased risk of colorectal cancer, but also increased risk of invasion.

Relatively small Hungarian study looked in patients with colorectal cancer only at one RAGE polymorphism ( -429 $\mathrm{T}>\mathrm{C}$ ) in parallel with other 3 polymorphisms of genes ( $\mathrm{TNF} \alpha$, LTA and HSP70) located in the same major histocompatibility complex (MHC) region (clas III) on the short arm of chromosome 6 [37]. Although the occurrence of this RAGE polymorphism did not differ from healthy controls, frequency of ancestral haplotype (TNF-alpha -308A, RAGE -429C, HSP70-2 -1267G, LTA $252 \mathrm{G}-8.1 \mathrm{AH}$ ) was significantly more frequent (2.5 times) among patients with colorectal cancer with higher risk in old subjects and in females suggesting the risk of altered immune response associated with this haplotype in the pathogenesis of colorectal (and possibly also ovarian) cancer.

In a murine model targeted ablation of RAGE diminished the autophagy (programmed cell survival, lysosome-mediated self-digestion) and attenuated the development of early pancreatic neoplasia [38] possibly through IL-6-induced phosphorylation of STAT3 with its subsequent mitochondrial localization which results in increased cellular proliferation. Targeted ablation of RAGE delayed the development of neoplasia, decreases the levels of autophagy and inhibits mitochondrial STAT3 activity and subsequent ATP production [35].

RAGE contributes also to the intratumoral accumulation of myeloid-derived suppressor cells during pancreatic carcinogenesis [39]. In mice the absence of RAGE delayed the development of neoplasia by limiting the accumulation of myeloid-derived suppressor cells expressing an oncogenic variant of Kras resulting in the accumulation of non-immunosuppressive macrophages [39]. Both studies suggest an important role of RAGE in the early phase of pancreatic carcinogenesis.

Polymorphisms of RAGE (RAGE -429T/C, -374T/A, 2184A/G, Gly82Ser) were also studied in patients with pancreatic cancer [40]. No difference in allelic and genotype 
Table 2. Types of cancer associated with the activation of RAGE

\begin{tabular}{|c|c|c|}
\hline Type of cancer & $\begin{array}{l}\text { Membrane RAGE } \\
\text { and RAGE polymorphisms }\end{array}$ & Soluble RAGE \\
\hline Lung cancer & $\begin{array}{l}\text { RAGE abundant in normal lung, but less expressed (or non } \\
\text { expressed) in NSCLC }[28,29] \text {, lung expression of RAGE may } \\
\text { disrupt normal cell-cell communication and enhance tumor } \\
\text { growth and metastasis }[31] \text {, genetic polymorphisms of RAGE } \\
\text { associated with susceptibility for NSCLC }[32,33]\end{array}$ & $\begin{array}{l}\text { Alternate splice variant RAGEv1 encoding esRAGE downregu- } \\
\text { lated in lung cancer [15], } \\
\text { Levels of sRAGE } \downarrow \text { in lung cancer, negatively correlated with } \\
\text { lymph node involvement and positively correlated with } \downarrow \\
\text { expression of RAGE in the lung cancer tissue [29]. }\end{array}$ \\
\hline Esophageal cancer & Expression of RAGE and its splice variants increased [29] & \\
\hline Gastric cancer & $\begin{array}{l}\text { A Gly82Ser polymorphism associated with gastric cancer and inva- } \\
\text { sion of gatric cancer [34] }\end{array}$ & \\
\hline Colorectal cancer & $\begin{array}{l}\text { RAGE highly expressed [22], } \\
\uparrow \text { RAGE expression in primary tumor correlates with the formation } \\
\text { of metastases and reduced survival [35], } \\
\text { Gly82Ser RAGE polymorphism associated in Chinese population } \\
\text { with the risk and invasion of colorectal cancer [36] }\end{array}$ & $\begin{array}{l}\text { Inverse association between sRAGE and colorectal adenoma } \\
\text { among pts without hypertension [13], inverse relation between } \\
\text { sRAGE and colorectal cancer [65] }\end{array}$ \\
\hline Hepatocellular cancer & RAGE highly expressed [22] & $\begin{array}{l}\text { sRAGE inversely associated with liver cancer [63], sRAGE } \\
\text { predicted the response to transarterial chemoembolization of } \\
\text { liver cancer [64], }\end{array}$ \\
\hline Pancreatic cancer & $\begin{array}{l}\text { In a murine model targeted ablation of RAGE delayed the develop- } \\
\text { ment of pancreatic neoplasia [38], Absence of RAGE in mice delayed } \\
\text { the development of pancreatic neoplasia [39], polymorphisms of } \\
\text { RAGE not associated with pancreatic cancer [40] }\end{array}$ & $\begin{array}{l}\text { sRAGE levels inversely associated with pancreatic } \\
\text { cancer [61], } \\
\text { sRAGE levels } \downarrow \text { in pacreatic cancer ( } \downarrow \downarrow \text { in diabetics with } \\
\text { pancreatic cancer [40], } \\
\text { no association between levels of esRAGE and pancreatic cancer } \\
\text { with the exception of patients with shorter follow-up [62] }\end{array}$ \\
\hline Kidney cancer & $\begin{array}{l}\text { AGE modified proteins induced growth of renal cancer cells prob- } \\
\text { ably through RAGE activation [41], increased co-expression of } \\
\text { RAGE and HMGB1 on renal cancer cells correlated with the tumor } \\
\text { size and clinical stage [42] }\end{array}$ & \\
\hline Prostate cancer & $\begin{array}{l}\text { RAGE and HMGB1 coexpressed by the cells of prostate cancer, } \\
\text { associated with PSA, clinical stage and poor survival in advanced } \\
\text { prostate cancer [43], silencing RAGE } \downarrow \text { PSA levels, inhibited tumor } \\
\text { growth in the mouse model of prostate cancer [44], AGEs induce } \\
\text { invasion and growth in the hormone-independent prostate cell } \\
\text { line [45] }\end{array}$ & $\begin{array}{l}\text { Alternate splice variant RAGEv1 encoding esRAGE downregu- } \\
\text { lated in prostate cancer [15] }\end{array}$ \\
\hline Ovarian cancer & $\begin{array}{l}\text { 82G/S polymorphism of RAGE associated with epithelial ovarian } \\
\text { cancer [47] }\end{array}$ & \\
\hline Cervical cancer & $\begin{array}{l}\text { 82G/S polymorphism of RAGE associated with cervical squamous } \\
\text { cell cancer and HPV infection [48] }\end{array}$ & $\begin{array}{l}\text { 82G/S polymorphism of RAGE associated in cervical cancer } \\
\text { with lower soluble RAGE [48] }\end{array}$ \\
\hline Breast cancer & $\begin{array}{l}\text { Estrogens induce RAGE expression on breast cancer cells and } \\
\text { prolong their survival [49], RAGE highly expressed in breast } \\
\text { cancer [22], } \\
\text { RAGE expression correlated with the levels of AGE modified } \\
\text { proteins [24], } \\
\text { no difference in genetic polymorphisms of RAGE between breast } \\
\text { cancer and healthy controls [50,51], } \\
\text { rs184003 polymorphism and T-T-G-Thaplotype more frequent in } \\
\text { breast cancer compared to healthy controls [52] }\end{array}$ & $\begin{array}{l}\text { Lower sRAGE levels in breast [50], but increasing in pts with } \\
\text { advanced breast cancer, lower grade, positive estrogen recep- } \\
\text { tors, and intermediate positivity of Her2/neu, genetic polymor- } \\
\text { phisms of RAGE related to serum levels of RAGE [50] }\end{array}$ \\
\hline Melanoma & $\begin{array}{l}\text { RAGE silencing inhibits migration of melanoma cells [53], } \uparrow \text { RAGE } \\
\text { on human metastatic melanoma a cell line associated with metastatic } \\
\text { phenotype [54], } \\
\text { Anti-RAGE antibodies [55], or DNA-AGE aptamer inhibited the } \\
\text { growth of melanoma cells and tumor-associated angiogenesis [57], } \\
\text { RAGE expression } \uparrow \text { in melanoma than in nevus pigmentosus and } \\
\uparrow \uparrow \text { in metastatic melanoma [58], } \\
\text { pretreatment of melanoma cells with anti-RAGE antibody sup- } \\
\text { pressed formation of pulmonary metastases in uteroglobin knockout } \\
\text { mice [59] }\end{array}$ & \\
\hline Brain tumors & & $\begin{array}{l}\text { Alternate splice variant RAGEv1 encoding esRAGE downregu- } \\
\text { lated in brain tumors [15] }\end{array}$ \\
\hline
\end{tabular}


frequencies in all studied RAGE polymorphisms among the patients with pancreatic cancer and controls was found.

In an early in vitro study AGE modified proteins (AGEmodified bovine serum albumin) showed a tendency to induce the cell growth of the renal cancer cells and promoted the production of IL- 6 which may serve as an autocrine growth factor [41]. Renal cancer cells were shown to express mRNA for RAGE and the putative effect of AGEs on renal cancer cells was probably mediated by RAGE. In another study, elevated co-expression of RAGE and HMGB1 on renal cancer cells correlated with the tumor size and clinical stage [42]. HMGB1 time- and dose-dependent induction of ERK1/2 could have been partially reversed by RAGE knockdown with similar partial reversal of HMGB1- stimulated cell proliferation, migration and invasion.

RAGE and HMGB1 are believed to play an important role in prostate cancer and are associated with its progression and poor survival. RAGE and HMGB1 were expressed in $78.8 \%$ and $68.2 \%$ of cases of prostate cancer, respectively [43], usually both proteins were co-expressed and their expression strongly correlated. Expression of RAGE and HMGB1 was associated with the clinical stage and PSA level, but not with the Gleason score, but it was asssociated with poor survival in patients with stage III and IV prostate cancer. RAGE and HMGB1 could be thus be potentially useful biomarkers and potential therapeutic targets in prostate cancer. Silencing the expression of RAGE by RNAi downregulated RAGE expression, reduced PSA levels, inhibited cell proliferation of both androgen-dependent and androgen-independent prostate cancer cells and resulted in the apoptotic elimination of prostate cancer cells due to the induction of caspase- 8 and caspase- 3 signaling and inhibited tumor growth in the mouse model of prostate cancer [44]. Both androgen-dependent and androgen-independent prostate cancer cell interacted with soluble RAGE through the V domain of RAGE and this adhesion had to be blocked by AGE-modified proteins and antibodies against RAGE, but not by $\mathrm{S} 100 \mathrm{~B}$, or amphoterin (HMGB1) suggesting that AGEs may be the major ligand of RAGE on prostate cancer cells [45]. In prostate tissue untreated prostate cancer and hormone-refractory prostate cancer had higher RAGE and HMGB1 mRNA expression compared to normal prostate tissue and AGE-modified bovine serum albumin induced invasion and growth in the hormone-independent prostate cell line [46].

Out of three RAGE polymorphisms ( $82 \mathrm{G}>\mathrm{S},-374 \mathrm{~T}>\mathrm{A},-429$ $\mathrm{C}>\mathrm{T}$, and $1704 \mathrm{G}>\mathrm{T}$ ) studied in epithelial ovarian carcinoma (EOC) [47] only the frequencies of the $82 \mathrm{G}>\mathrm{S}$ polymorphisms were significantly different between the EOC cases and controls. The 82SS genotype was significantly higher in EOC patients than in controls and 82SS polymorphism increased the risk of EOC compared to the 82 GG genotype 2.65 times after adjustment for age, smoking status, body mass index, family history, usage of contraceptives, tubal ligation history, use of menopausal hormones and menopausal status. The $82 \mathrm{~S}$ allele carriage presented a 1.71 times higher risk for EOC suggesting that that the $82 \mathrm{G}>\mathrm{S}$ polymorphism of RAGE gene may be associated with the susceptibility of EOC.

The same three RAGE polymorphisms $(-429 \mathrm{~T}>\mathrm{C}$, $-374 \mathrm{~T}>\mathrm{A}, 1704 \mathrm{G}>\mathrm{T}$, and $82 \mathrm{G}>\mathrm{S}$ ) and human papillomavirus (HPV) infection were also studied in patients with cervical squamous cell cancer [48]. Only in $82 \mathrm{G}>\mathrm{S}$ polymorphism genotype distributions and allele frequencies were significantly different between the two groups. The cervical cancer patients had markedly higher percentage of $82 \mathrm{G}>\mathrm{S}$ carriage than controls. The $82 \mathrm{G}>\mathrm{S}$ genotype was associated with significantly elevated risk $(\mathrm{HR}=1.98)$ for cervical cancer. In addition, the $82 \mathrm{G}>\mathrm{S}$ carriers had significantly lower serum soluble RAGE (sRAGE) levels compared to patients with $82 \mathrm{GG}$ polymorphism. The polymorphisms of $-429 \mathrm{~T}>\mathrm{C},-374 \mathrm{~T}>\mathrm{A}$ and $1704 \mathrm{~T}>\mathrm{G}$ did not affect the cervical cancer risk and the serum sRAGE levels. The 82GS and 82SS genotype carriers in the HPV infection subgroup had increased risk for cervical cancer versus 82GG $(\mathrm{OR}=1.68$ and 1.74, respectively, both $\mathrm{P}<0.05)$. This trend was not observed in the subgroup with no detectable HPV DNA. The RAGE $82 \mathrm{G}>\mathrm{S}$ polymorphisms, interacting with HPV infection thus seems to be implicated in the occurrence of cervical cancer.

Treatment of MCF-7 breast cancer cells with 17a-ethinyl estradiol activated NF- $\mathrm{kB}$ and enhanced RAGE expression. RAGE activated expression of cell cycle protein cyclin D1, enhanced phosphorylation of prosurvival protein Akt and increased expression of antiapoptotic protein Bcl-2 thus enhancing survival of breast cancer cells [49]. RAGE may thus mediate the proliferation stimulating effect of estrogens on breast cancer cells.

In our own study [50] we found no difference in RAGE polymorphisms between patients with breast cancer and healthy controls, but serum levels of sRAGE were also influenced genetically (were related to Gly82Ser and 2184 AG polymorphisms of the RAGE gene). Another smaller study also found no difference between RAGE ( $-374 \mathrm{~T} / \mathrm{A},-429 \mathrm{~T} / \mathrm{C}$, and $63 \mathrm{bp} \mathrm{Ins/del)} \mathrm{polymorphism} \mathrm{among} \mathrm{patients} \mathrm{with} \mathrm{breast}$ cancer and healthy controls [51], but in a recent large study in Han Chinese [52] one out of four studied polymorphisms (rs184003) significantly differed between breast cancer patients and controls with patients carrying the rs $184003 \mathrm{~T}$ allele exhibiting 1.62 fold increased risk of breast cancer. There was also a significantly more frequent occurrence of T-T-G-T haplotype (of rs1800625, rs1800624, rs2070600, and rs184003, respectively) conferring 1.43 fold increase in the adjusted risk of breast cancer.

In melanoma RAGE silencing by RNAi selectively inhibited migration of melanoma cells [53]. Overexpresssion of RAGE on human melanoma cell line associated with the upregulation of S100B and downregulation of p53, ERK1/2, cyclin E and NF- $\kappa B$. RAGE may play a role in the metastatic switch of the melanoma cells [54]. Administration of anti-RAGE antibodies [55], or DNA AGE-aptamer (a short sequence of DNA or RNA with high affinity to cognate ligands [56]) to nude mice 
with infused melanoma cells significantly inhibited tumor growth, number of tumor-associated vessels and decreased expression levels of proliferating nuclear antigen [57]. Expression of RAGE, S100P and cytoskeletal protein ezrin which all play a role in tumor growth, invasion and metastasis were significantly higher (and closely correlating) in melanoma than in nevus pigmentosus and higher expression levels were observed in metastatic compared to primary melanomas [58]. Pretreatment of melanoma cells with anti-RAGE antibody suppressed migration and invasion and formation of pulmonary metastases of melanoma cells in uteroglobin knockout mice [59]. All these data suggesting a role of RAGE in melanoma growth and formation of metastases.

\section{sRAGE in cancer (table 2)}

Some RAGE splicing variants, e.g. RAGE variant 1 (RAGEv1) can provide a major soluble form of RAGE in blood circulation, which can neutralize deleterious ligands, thus diminishing signaling that can lead to inflammation and pathogenesis in cancer cells [60]. High degree of RAGEv1 expression was shown to decrease the transcription of of NF$\mathrm{kB}$ and TNF- $\alpha$ in hepatic HepG2 cancer cells suggesting its putative therapeutic potential.

Alternate splice variant termed RAGE splice variant 1 (RAGEv1), which encodes a soluble endogenous form of the receptor that inhibits tumorigenesis, cell invasion and angiogenesis is downregulated in lung, prostate, and brain tumors relative to control matched tissues [22]. Tumors expressing RAGEv1 were significantly smaller than wild-type tumors and displayed prominently reduced activation of JNK. RAGEv1 would thus serve as a suppressor of the tumor growth with apparent putative therapeutic implications [15].

Cigarette smoking, obesity, type 2 diabetes, and, to a lesser extent, meat cooked at high temperatures are associated with pancreatic cancer [61]. Cigarette smoke and foods cooked at higher temperatures are major environmental sources of advanced glycation end products (AGE). In a large prospective study in the Finnish male smokers CML-AGE levels were not associated with pancreatic cancer. In contrast, sRAGE levels were inversely associated with pancreatic cancer (fifth compared with first quintile, $R R=0.46$ ). Further adjustment for glucose or insulin levels did not change the observed associations. This study suggests that sRAGE is inversely associated with pancreatic cancer risk among Finnish male smokers.

In another study sRAGE was decreased in patients with pancreatic cancer compared to patients with diabetes mellitus and controls. Patients with pancreatic cancer and impaired glucose tolerance had lower sRAGE levels compared to patients with pancreatic cancer without impaired glucose tolerance. No relationship of sRAGE to the stage of pancreatic cancer was, however, found [40]. The lowest RAGE levels were found in patients with pancreatic cancer and impaired glucose tolerance supporting the role of impaired glucose metabolism disorder in cancerogenesis.
There was no correlation between esRAGE and the risk of pancreatic cancer [62], however, there was an inverse association between esRAGE and risk of pancreatic cancer for cases that were diagnosed within the first 2 years of follow-up (HR $=0.46$ ). In a large study in a prospectively followed Finnish population sRAGE and CML-AGE concentrations were inversely associated with liver cancer [63]. Further adjustment for glucose and insulin or exclusion of case subjects with chronic HBV or HCV did not change the associations.

In hepatocellular cancer there was and early decrease of sRAGE after transarterial chemoembolization (TACE) therapy (an effective locoregional treatment [64]). Pretherapeutic and 24 -h values of sRAGE were significantly higher in the no progression group than those in the progression group suggesting that sRAGE could serve as a predictor of outcome in patients with liver cancer undergoing TACE therapy.

In a colonoscopy-based case-control study patients with colonic adenoma had insignificanty lower levels of sRAGE than controls. Patients in the highest compared to the lowest category had HR $=0.55$ of colorectal adenoma. The inverse association between sRAGE and colorectal adenoma was seen only among those patients without hypertension [65]. An inverse association between sRAGE and colorectal adenoma was in line with an inverse association between sRAGE and colorectal cancer previously reported [65]. In this study in the prospective cohort of the Finnish male smokers patients in the highest quintile of sRAGE had compared to patients in the lowest sRAGE quintile 35\% lower risk for incident colorectal cancer after adjustment for for age, years of smoking, body mass index, and CMLAGE. Further adjustment for serum glucose strengthened the association $(\mathrm{RR}=0.52)$.

In patients with lung cancer patients serum sRAGE was significantly decreased compared with to healthy controls and patients with pulmonary tuberculosis. Lower sRAGE concentration was negatively correlated with lymph node involvement. Lower sRAGE concentrations also correlated with lower membranous and lung expression of RAGE in the lung cancer tissue $[29,30]$.

We recently studied the role of RAGE in 120 patients with breast cancer [50]. In our study patients with breast cancer had despite higher AGEs significantly lower serum levels of sRAGE compared to healthy controls $(1581+/-777$ versus $1803+/-632 \mathrm{ng} / \mathrm{mL}, \mathrm{p}<0.05)$. Serum levels of sRAGE were higher in patients with advanced breast cancer (stage III), lower grade and positive estrogen receptors, and intermediate positivity of $\mathrm{Her} 2 /$ neu receptors and were also influenced genetically (Gly82Ser and $2184 \mathrm{AG}$ polymorphisms of the RAGE gene). Decreased sRAGE levels in patients with breast cancer may contribute to the progression of the disease. Patients with better outcome (low grade and positive estrogen receptors) have higher sRAGE levels. Progression of the disease, may, however, increase sRAGE levels, possibly as a compensatory mechanism to counteract further progression. 


\section{Targeting RAGE and its ligands - can it contribute to the treatment of cancer?}

Activity of RAGE may be suppressed in many different ways using already available drugs (angiotensin receptor blockers, statins, metformin) which may e.g. interfere with RAGE signaling, or more specifically targeting RAGE ligands, or directly RAGE (anti-RAGE antibodies, recombinant sRAGE), or interfering with RAGE synthesis (e.g. AGE-RAGE aptamers, or RAGE silencing RNAs).

In diabetic nephropathy both statins and angiotensin receptor blockers were shown to inhibit the RAGE signaling [66, 67], but there are no data showing that they could inhibited tumor growth through the inhibition of RAGE signaling. Pravastatin dose-dependently inhibited the AGEs-induced up-regulation of RAGE mRNA level, ROS generation and apoptosis in human renal proximal tubular cells [66] and its effect on renal tubular cells could have been blocked by geranylgeranyl pyrophosphate (GGPP) suggesting that pravastatin suppresses the RAGE expression via inhibition of GGPP synthesis. Similarly, angiotensin receptor blocker, irbesartan, inhibited the AGE-induced up-regulation of RAGE mRNA levels, ROS generation, increased expression of inflammatory, thrombogenic and fibrogenic genes expression in human proximal tubular cells and AGE-induced apoptosis of these cells [67].

Increased cancer risk in patients with type 2 diabetes in mediated by insulin/insulin-like growth factor-I (IGF-I). Human epidermal growth factor receptor (HER2), insulin receptor and IGF-I receptor involve the same $\mathrm{PI} 3 \mathrm{~K} / \mathrm{AKT} / \mathrm{mTOR}$ signaling, and different antidiabetic pharmacotherapy may differentially affect this pathway, leading to different prognosis of HER2+ breast cancer. Peroxisome proliferator-activated receptorgamma (PPARgamma) agonists were also shown to interfere with the AGE-RAGE system [68].

In diabetic patients with breast cancer metformin $(\mathrm{HR}=$ $0.52)$ and thiazolidinediones $(\mathrm{HR}=0.41)$ predicted lengthened survival, and competing risk analysis showed that metformin and thiazolidinediones were associated with decreased breast cancer-specific mortality $(\mathrm{HR}=0.47$ and $\mathrm{HR}=0.42$, respectively). So the choice of antidiabetic pharmacotherapy may influence prognosis of this group [69]. The effect of metformin may be at least partly mediated by the interference with AGERAGE system. AGEs induced proliferation of breast cancer cells could have been completely prevented by metformin [70]. Metformin also completely suppressed the AGE-induced upregulation of RAGE and VEGF mRNA. This inhibitory effect of metformin could have been significantly blocked by the inhibitor of AMP-activated protein kinase. AMP-activated protein kinase pathway. Metformin may protect against breast cancer expansion in diabetic patients possibly at least partly by blocking the AGEs-RAGE axis.

Insulin was also suggested (based on in vitro studies) to increase the cleavage of full-length RAGE mRNA with the resultant release of esRAGE and sRAGE. As insulin seems to increase both the expression of RAGE and the formation of its putative inhibitor sRAGE the overall effect of insulin on the activation of RAGE system is uncertain [71].

Retinol supplementation was shown to increase the incidence of lung cancer and increase mortality in smokers. This effect may be mediated by the retinol-induced free radical production and oxidative stress (partly compensated by increased antioxidant enzyme activity) and oxidative damage and downregulation of RAGE demonstrated also in the human lung cancer cell line. Retinol-induced downregulation of RAGE was mediated by p38MAPK activation which was inhibited by the analog of $a$-tocopherol suggesting that the activation of MAPK was redox-dependent. Downregulation of RAGE by retinol was also mediated through the MAPK induced activation of NF- $\kappa B$ as inhibition of NF- $\kappa B$ by siRNA blocked the effect of retinol on RAGE [72]. Normal expression of RAGE (as already stressed) is important for the normal maintenance of lung function and its downregulation may enhance (at least in some experimental models) lung carcinogenesis suggesting that any systemic administration of anti-RAGE treatment may have some inherents risks.

Heparin has not only anticoagulant, but also broad antiinflammatory activity. Low anti-coagulant derivative of heparin (2-O,3-O-desulfated heparin - ODSH) with preserved antiinflammatory activity disrupts (similarly as heparin) Mac-1 (CD11b/CD18)-mediated leukocyte adhesion to RAGE and inhibits the activation of RAGE by its many proinflammatory ligands, including AGEs, HMGB1 and S100 calgranulins. In mice ODSH was more effective than heparin in reducing selectin-mediated lung metastasis of melanoma and inhibited RAGE- mediated airway inflammation after intratracheal HMGB1 administration showing its potential in treatment of some malignancies [73].

Altered expression of chondrotin sulfate (CS) and heparan sulfate (HS) at the surface of tumor cell plays a key role in malignant transformation and tumor metastasis and the lung cancer cells with greater metastatic potential may have a higher proportion of E-disaccharide units in CS chains than lung cancer cells with low metastatic potential. Metastasis may have been inhibited by pre-administration of CS-E from squid cartilage rich in E units or by antibodies against CS-E. As already mentioned RAGE is a receptor molecule of CS chains containing E-disaccharides and binds also strongly to heparan-sulfate expressing lung cancer cells and anti-RAGE antibody inhibits the colonization of the lungs by lung cancer cells. Both CS and HS and RAGE should be potential molecular targets of the treatment of pulmonary metastasis [74].

Different interventions may be aimed at multiple RAGE ligands, e.g. activity of HMGB-1 can be blocked in several different ways [75]: by anti-HMGB-1 antibodies, by the inhibition of HMGB-1 release from the nucleus into the extracellular space, by HMGB-A box, a competitive antagonist of HMGB-1, by blockage of RAGE-HMGB-1 signaling using RAGE antagonists, by blockage of TLR-HMGB-1 signaling using anti-TLR2 antibodies and by other molecules that modulate HMGB-1 activity using e.g. human soluble thrombomodulin. 
Another therapeutic target may be S100 proteins, an example may be S100P. S100P interaction with RAGE can be also blocked by the antiallergic drug cromolyn and high concentrations of cromolyn improve gemcitabine effectiveness in pancreatic ductal adenocarcinoma. Cromolyn analog 5-methyl cromolyn was more effective in inhibiting S100P-induced increase of NF- $\mathrm{KB}$, cell growth and apoptosis and cromolyn derivatives may be promising drugs to block S100P in different types of cancer [76]. Small S100P-derived RAGE antagonist peptide (RAP) blocking activation of RAGE by multiple ligands was recently developed [77] and was shown to inhibit the interaction of S100P, S100A4, and HMGB-1 with RAGE at micromolar concentrations. RAP also reduced the ability of the ligands to stimulate RAGE activation of NFKB in cancer cells in vitro and in vivo. Importantly, systemic administration of RAP reduced the growth and metastasis of pancreatic tumors and also inhibited glioma tumor growth.

Finally, there can be direct intervention against RAGE. Antibodies against RAGE were shown to inhibit metastasis of lung cancers and melanoma cells [10]. AGEs induced proliferation of breast cancer cells could have been also completely prevented by anti-RAGE antibodies [70]. Administration of recombinant soluble RAGE was shown to block RAGE signaling pathway in animal models suggesting that the circulating sRAGE could protect the tissue againgst RAGE-induced tissue damage [22]. Decrease in the proliferation of all sub-types of experimental breast cancer, MCF-7, SK-Br-3 and MDA-MB-231 in which RAGE expression levels correlated with the degree of severity of breast cancer may have been induced by RAGE siRNA [78]. RAGE siRNA arrested breast cancer cells in the G1 phase and inhibited DNA synthesis by decreasing the expression of transcriptional factor NF- $\kappa B$ p 65 as well as the expression of cell proliferation markers PCNA and cyclinD1.

RAGE and RAGE ligands can thus be considered as possible targets for the treatment of different types of although it remains very uncertain if the promising data from cell cultures and experimental models could be translated into clinically useful anti-cancer tool. Apparently these specific modes of the RAGE inhibition may be promising not only in cancer, but also in diabetes, different inflammatory and neurodegenerative disorders.

Acknowledgements: Studies of the authors on RAGE were supported by research projects MH CZ - RVO VFN 64641 VFN 64164 and PRVOUK - P25/LF1/2.

\section{References}

[1] JEANNIN P, JAILLON S, DELNESTE Y. Pattern recognition receptors in the immune response against dying cells. Curr Opin Immunol 2008, 20: 530-537. http://dx.doi.org/10.1016/j. $\underline{\text { coi.2008.04.013 }}$

[2] KAMAGAI Y, AKIRA S. Identification and functions of pattern-recognition receptors. J Allergy Clin Immunol 2010, 125: 985-992. http://dx.doi.org/10.1016/j.jaci.2010.01.058
[3] SIMS GP, ROWE DC, RIETDIJK ST, HERBST R, COYLE AJ. HMGB1 and RAGE in inflammation and cancer. Annu Rev Immunol, 2010, 28: 367-388. http://dx.doi.org/10.1146/ annurev.immunol.021908.132603

[4] FRITZ G. RAGE: a single receptor fits multiple ligands. Cell 2011, 36: 625-632. http://dx.doi.org/10.1016/j. tibs.2011.08.008

[5] LIN L. RAGE on the Toll road? Cell Mol Immunol, 2006, 3: 351-356.

[6] IBRAHIM ZA, ARMOUR CL, PHIPPS S, SUKKAR MB. RAGE and TLRs: relatives, friends or neighbours? Mol Immunol, 2013, 56: 739-744. http://dx.doi.org/10.1016/j. molimm.2013.07.008

[7] SPARVERO LJ, ASAFU-ADJEI D, KANG R, TANG D, AMIN N, et al. RAGE (Receptor for Advanced Glycation Endproducts), RAGE ligands, and their role in cancer and inflammation. J Transl Med, 2009, 17;7:17. http://dx.doi. org/10.1186/1479-5876-7-17

[8] RAUCCI A, CUGUSI S, ANTONELLI A, BARABINO SM, MONTI L, et al. A soluble form of the receptor for advanced glycation endproducts (RAGE) is produced by proteolytic cleavage of the membrane-bound form by the sheddase a disintegrin and metalloprotease 10 (ADAM10). FASEB J, 2008, 22: 3716-3727. http://dx.doi.org/10.1096/fj.08-109033

[9] LOTZE MT, DEMARCO RA. Dealing with death: HMGB1 as a novel target for cancer therapy. Curr Opin Investig Drugs, 2003, 4: 1405-1409.

[10] MIZUMOTO S, SUGAHARA K. Glycosaminoglycans are functional ligands for receptor for advanced glycation endproducts in tumors. FEBS J, 2013, 280: 2462-2470. http:// dx.doi.org/10.1111/febs.12156

[11] RAI V, TOURE F, CHITAYAT S, PEI R, SONG F, et al. Lysophosphatidic acid targets vascular and oncogenic pathways via RAGE signaling. J Exp Med, 2012, 209: 2339-2350. http:// dx.doi.org/10.1084/jem.20120873

[12] RAMASAMY R, YAN SF, SCHMIDT AM. RAGE: therapeutic target and biomarker of the inflammatory response-the evidence mounts. J Leukoc Biol, 2009, 86: 505-512. http:// dx.doi.org/10.1189/jlb.0409230

[13] JIAO L, CHEN L, ALSARRAJ A, RAMSEY D, DUAN Z, et al. Plasma soluble receptor for advanced glycation end-products and risk of colorectal adenoma. Int J Mol Epidemiol Genet, 2012, 3: 294-304.

[14] HAN S-H, KIM YH, MOOK-JUNG I. RAGE: the beneficial and deleterious effects by diverse mechanisms of actions. Mol Cells, 2011, 31: 91-97. http://dx.doi.org/10.1007/s10059-011-0030-x

[15] KALEA AZ, SEE F, HARJA E, ARRIERO MU, SCHMIDT AM, et al. Alternatively spliced RAGEv1 inhibits tumorigenesis through suppression of JNK signaling. Cancer Res, 2010, 70: 5628-5638.

[16] BIERHAUS A, HUMPERT PM, MORCOS M, WENDT T, CHAVAKIS T, et al. Understanding RAGE, the receptor for advanced glycation end products. J Mol Med, 2005, 83: 876-886. http://dx.doi.org/10.1007/s00109-005-0688-7

[17] HUDSON BI, CARTER AM, HARJA CE, KALEA AZ, ARRIERO M, et al. Identification, classification, and expression of RAGE gene splice variants. FASEB J, 2008, 22: 1572-1580. 
[18] STERENCZAK KA, NOLTE I, MURUA ESCOBAR H. RAGE splicing variants in mammals. Methods Mol Biol, 2013, 963: 265-276. http://dx.doi.org/10.1007/978-1-62703230-8 16

[19] SORCI G, RIUZZI F, GIAMBANCO I, DONATO R, et al. RAGE in tissue homeostasis, repair and regenaration. Biochim Biophys Acta, 2013, 1833: 101-109.

[20] SANTILLI F, VAZZANA N, BUCCIARELLI LG, DAVI G. Soluble forms of RAGE in human diseases: clinical and therapeutical implications. Curr Med Chem, 2009, 16: 940-952. http://dx.doi.org/10.2174/092986709787581888

[21] VAZZANA N, SANTILLI F, CUCCURULLO C, DAVI G, et al. Soluble forms of RAGE in internal medicine. Intern Emerg Med, 2009, 4: 389-401. http://dx.doi.org/10.1007/s11739-009 -0300-1

[22] KOSTOVA N, ZLATEVA S, UGRINOVA I, PASHEVA E, et al. The expression of HMGB1 protein and its receptor RAGE in human malignant tumors. Mol Cell Biochem, 2010, 337: 251-258. http://dx.doi.org/10.1007/s11010-009-0305-0

[23] YAMAGISHI S, MATSUI T. Soluble form of a receptor for advanced glycation endproducts as a biomarker. Front Biosci (Elite Ed.), 2010, 2: 1184-1195. http://dx.doi.org/10.2741/ $\underline{\mathrm{E} 178}$

[24] KORWAR AM, BHONSLE HS, CHOUGALE AD, KOTE SS, GAWAI KR, et al. Analysis of AGE modified proteins and RAGE expression in HER2/neu negative invasive ductal carcinoma. Biochem Biophys Res Commun, 2012, 419: 490-494. http://dx.doi.org/10.1016/j.bbrc.2012.02.039

[25] TAFANI M, SCHITO L, PELLEGRINI L, VILLANOVA L, MARFE G, et al. Hypoxia-increased RAGE and P2X7R expression regulates tumor cell invasion through phosphorylation of Erk1/2 and Akt and nuclear translocation of NF- $\kappa$ B. Carcinogenesis, 2011, 32: 1167-1175. http://dx.doi. org/10.1093/carcin/bgr101

[26] OSAWA M, YAMAMOTO Y, MUNESUE S, MURAKAMI $\mathrm{N}$, SAKURAI S, et al. De-N-glycosylation or G82S mutation of RAGE sensitizes its interaction with advanced glycation endproducts. Biochim Biophys Acta, 2007, 1770: 1468-74.

[27] PARK SJ, KLEFFMANN T, HESSIAN PA. The G82S polymorphism promotes glycosylation of the receptor for advanced glycation end products (RAGE) at asparagine 81: comparison of wild-type rage with the G82S polymorphic variant. J Biol Chem, 2011, 286: 21384-92. http://dx.doi. org/10.1074/jbc.M111.241281

[28] SCHENK S, SCHRAML P, BENDIK I, LUDWIG CU. A novel polymorphism in the promoter of the RAGE gene is associated with non-small cell lung cancer. Lung Cancer, 2001, 32: 7-12. http://dx.doi.org/10.1016/S0169-5002(00)00209-9

[29] JING RR, CUI M, SUN BL, YU J, WANG HM, et al. Tissuespecific expression profiling of receptor for advanced glycation end products and its soluble forms in esophageal and lung cancer. Genet Test Mol Biomarkers, 2010, 14: 355-361. http:// dx.doi.org/10.1089/gtmb.2009.0064

[30] JING R, CUI M, WANG J, WANG H. Receptor for advanced glycation end products (RAGE) soluble form (sRAGE): a new biomarker for lung cancer. Neoplasma, 2010, 57: 55-61. http:// dx.doi.org/10.4149/neo $2010 \quad 01 \quad 055$
[31] MARINAKIS E, BAGKOS G, PIPERI C, ROUSSOU P, DIAMANTI-KANDARAKIS E, et al. Critical role of RAGE in lung physiology and tumorigenesis: a potential target of therapeutic intervention? Clin Chem Lab Med, 2014, 52: 189-200. http://dx.doi.org/10.1515/cclm-2013-0578

[32] WANG X, CUI E, ZENG H, HUA F, WANG B, et al. RAGE genetic polymorphisms are associated with risk, chemotherapy response and prognosis in patients with advanced NSCLC. PLos One, 2012, 2012;7(10):e43734. Epub 2012 Oct 5. http:// dx.doi.org/10.1371/journal.pone.0043734

[33] PAN H, NIU W, HE L, WANG B, CAO J et al. Contributory role of five common polymorphisms of RAGE and APE1 genes in lung cancer among Han Chinese. PLoS One, 2013, 8: e69018, http://dx.doi.org/10.1371/journal.pone.0069018

[34] GU H, YANG L, SUN Q, ZHOU B, TANG N, et al. Gly82Ser polymorphism of the receptor for advanced glycation end products is associated with an increased risk of gastric cancer in a Chinese population. Clin Cancer Res, 2008, 14: 36272632. http://dx.doi.org/10.1158/1078-0432.CCR-07-4808

[35] DAHLMANN M, OKHRIMENKO A, MARCINKOWSKI P, OSTERLAND M, HERRMANN P, et al. RAGE mediates S100A4-induced cell motility via MAPK/ERK and hypoxia signaling and is a prognostic biomarker for human colorectal cancer metastasis. Oncotarget, 2014, 30: 3220-3223.

[36] QIAN F, SUN BL, ZHANG WY, KE J, ZHU J. Gly82Ser polymorphism of the receptor for advanced glycation end-product (RAGE) potential high risk in patients with colorectal cancer. Tumour Biol, 2014, 35:3171-3175. http://dx.doi.org/10.1007/ s13277-013-1414-7

[37] TOTH EK, KOCSIS J, MADARAS B, BIRO A, POCSAI Z, et al. The 8.1 ancestral MHC haplotype is strongly associated with colorectal cancer risk. Int J Cancer, 2007, 121: 1744-1748. http://dx.doi.org/10.1002/ijc.22922

[38] KANG R, TANG D, LOTZER MT, ZEH HJ 3RD. AGER/ RAGE-mediated autophagy promotes pancreatic tumorigenesis and bioenergetics through the IL6-pSTAT3 pathway. Autophagy, 2012, 8: 989-991. http://dx.doi.org/10.4161/ auto.20258

[39] VERNON PJ, LOUX TJ, SCHAPIRO NE, KANG R, MUTHUSWAMY R, et al. The receptor for advanced glycation end products promotes pancreatic carcinogenesis and accumulation of myeloid-derived suppressor cells. J Immunol, 2013, 190: 1372-1379. http://dx.doi.org/10.4049/ jimmunol.1201151

[40] KRECHLER T, JACHYMOVA M, MESTEK O, ZAK A, ZIMA T, et al. Soluble receptor for advanced glycation end-products (sRAGE) and polymorphisms of RAGE and glyoxalase I genes in patients with pancreas cancer. Clin Biochem, 2010, 43: 882-886. http://dx.doi.org/10.1016/j. clinbiochem.2010.04.004

[41] MIKI S, KASAYAMA S, MIKI YQ, NAKAMURA Y, YAMAMOTO M, et al. Expression of receptors for advanced glycosylation and products of renal cell carcinoma cells in vitro. Biochem Biophys Res Commun, 1993, 196: 984-989. http://dx.doi.org/10.1006/bbrc.1993.2346

[42] LIN L, ZHONG K, SUN Z, WU G, DING G. Receptor for advanced glycation end products (RAGE) partially mediates 
HMGB1-ERK activation in clear cell renal cell carcinoma. J Cancer Res Clin Oncol, 2012, 138: 11-22. http://dx.doi. org/10.1007/s00432-011-1067-0

[43] ZHAO CB, BAO JM, LU YJ, ZHAO T, ZHOU XH, et al. Coexpression of RAGE and HMGB1 is associated with cancer progression and poor patient outcome of prostate cancer. Am J Cancer Res, 2014, 4: 369-377.

[44] ELANGOVAN I, THIRUGNANAM S., Chen A, Zheng G, BOSLAND MC, et al. Targeting receptor for advanced glycation end products (RAGE) expression induces apoptosis and inhibits prostate tumor growth. Biochem Biophys Res Commun, 2012, 417: 1133-1138. http://dx.doi.org/10.1016/j. bbrc.2011.12.060

[45] ALLMEN EU, KOCH M, FRITZ G, LEGLER DF. V domain of RAGE interacts with AGEs on prostate carcinoma cells. Prostate, 2008, 68: 748-758. http://dx.doi.org/10.1002/pros.20736

[46] ISHIGURO H, NAKAIGAWA N, MIYOSHI Y, FUJINAMI K, KUBOTA Y, et al. Receptor for advanced glycation end products (RAGE) and its ligand, amphoterin are overexpressed and associated with prostate cancer development. Prostate, 2005, 64: 92-100. http://dx.doi.org/10.1002/ pros.20219

[47] ZHANG S, HOU XW, ZI S, WANG Y, CHEN L, et al. Polymorphisms of receptor for advanced glycation end products and risk of epithelial ovarian cancer in Chinese patients. Cell Physiol Biochem, 2013, 31: 525-531. http://dx.doi. org/10.1159/000350073

[48] XU Y, XUE F, YUAN B, ZHANG L, LI J, et al. The interaction between RAGE gene polymorphisms and HPV infection in determining the susceptibility of cervical cancer in a Chinese population. Cancer Biomark, 2012, 11: 147-153.

[49] LATA K, MUKHERJEE TK. Targeting RAGE and its ligandscan it contribute to the treatment of breast cancer? Biochim Biophys Acta, 2014, 1840: 1083-1091.

[50] TESAROVA P, KALOUSOVA M, JACHYMOVA M, MESTEK O, PETRUZELKA L, et al. Receptor for advanced glycation end products (RAGE) - soluble form (sRAGE) and gene polymorphisms in patients with breast cancer. Cancer Invest., 2007, 25: 720-725. http://dx.doi. org/10.1080/07357900701560521

[51] HASHEMI M, MOAZENI-ROODI A, ARBABI F, FAZAELO A, NASAB EE, et al. Genotyping of $-374 \mathrm{~A} / \mathrm{T},-429 \mathrm{~A} / \mathrm{G}$, and $63 \mathrm{bp}$ Ins/del polymorphisms of RAGE by rapid onestep hexaprimer amplification refractory mutation system polymerase chain reaction in breast cancer patients. Nucleosides Nucleotides Nucleic Acids, 2012, 31: 401-410. http:// dx.doi.org/10.1080/15257770.2012.665545

[52] PAN H, HE L, WANG B, NIU W. The relationship between RAGE gene four common polymorphisms and breast cancer risk in northeastern Han Chinese. Sci Rep, 2014. http://dx.doi. org/10.1038/srep04355

[53] POPA I, GANEA E, PETRESCU SM. Expression and subcellular localization of RAGE in melanoma cells. Biochem. Cell Biol, 2014, 92: 127-136. http://dx.doi.org/10.1139/bcb-2013$\underline{0064}$

[54] MEGHNANI V, VETTER SW, LECLERC E. RAGE overexpression confers a metastatic phenotype to the WM115 human primary melanoma cell line. Biochim Biophys Acta, 2014, 1842: 1017-1727.

[55] ABE R, SHIMIZU T, SUGAWARA H, WATANABE H, NAKAMURA H, et al. Regulation of human melanoma growth and metastasis by AGE-AGE receptor interactions. J Invest Dermatol, 2004, 122: 461-467. http://dx.doi.org/10.1046/ j.0022-202X.2004.22218.x

[56] SANTOSH B, YADAVA PK. Nucleic acid aptamers: research tools in disease diagnostics and therapeutics. Biomed Res Int, 2014, 2014: 540451.

[57] OJIMA A, MATSUI T, MAEDA S, TAKEUCHI M, INOUE $\mathrm{H}$, et al. DNA aptamer raised against advanced glycation end products inhibits melanoma growth in nude mice. Lab Invest, 2014, 94: 422-429. http://dx.doi.org/10.1038/ labinvest.2014.5

[58] ZHU L, ITO T, NAKAHARA T, NAGAE K, FUYUNO Y, et al. Upregulation of S100P, receptor for advanced glycation end products and ezrin in malignant melanoma. J Dermatol, 2013, 40: 973-979. http://dx.doi.org/10.1111/1346-8138.12323

[59] SAHA A, LEE YC, ZHANG Z, CHANDRA G, SU SB, et al. Lack of an endogenous anti-inflammatory protein in mice enhances colonization of B16F10 melanoma cells in the lungs. J Biol Chem, 2010, 285: 10822-10831. http://dx.doi. org/10.1074/jbc.M109.083550

[60] LERTWITTAYAPON T, TENCOMNAO T, SANTIYANONT R. Inhibitory effect of alternatively spliced RAGEv1 on the expression of NF-kB and TNF-alpha in hepatocellular carcinoma cells. Genet Mol Res, 2012, 29: 1712-1720. http://dx.doi. org/10.4238/2012.June.29.3

[61] JIAO L, WEINSTEIN SJ, ALBANES D, TAYLOR PR, GRAUBARD BI, et al. Evidence that serum levels of the soluble receptor for advanced glycation end products are inversely associated with pancreatic cancer risk: a prospective study. Cancer Res, 2011, 71: 3582-3589. http://dx.doi. org/10.1158/0008-5472.CAN-10-2573

[62] GROTE VA, NIETERS A, KAAKS R, TJONNELAND A, ROSWALL N, et al. The associations of advanced glycation end products and its soluble receptor with pancreatic cancer risk: a case-control study within the prospective EPIC cohort. Cancer Epidemiol Biomarkers Prev, 2012, 21: 619-628. http:// dx.doi.org/10.1158/1055-9965.EPI-11-1139

[63] MOY KA, JIAO L, FREEDMAN ND, WEINSTEIN SJ, SINHA $\mathrm{R}$, et al. Soluble receptor for advanced glycation end products and risk of liver cancer. Hepatology, 2013, 57: 2338-2345. http://dx.doi.org/10.1002/hep.26264

[64] KOHLES N, NAGEL D, JUNGST D, STIEBER P, HOLDENRIEDER S. Predictive value of immunogenic cell death biomarkers HMGB1, sRAGE and Dnase in liver cancer patients receiving transarterial chemoembolization therapy. Tumour Biol, 2012, 33: 2401-2409. http://dx.doi.org/10.1007/ s13277-012-0504-2

[65] JIAO L, TAYLOR PR, WEINSTEIN SJ, GRAUBARD BI, VIRTAMO J, et al. Advanced glycation end products, soluble receptor for advanced glycation end products, and risk of colorectal cancer. Cancer Epidemiol Biomarkers Prev, 2011, 20: 1430-1438. http://dx.doi.org/10.1158/1055-9965.EPI-11$\underline{0066}$ 
[66] ISHIBASHI Y, YAMAGISHI S, MATSUI T, OHTA K, TANOUE R, et al. Pravastatin inhibits advanced glycation end products (AGEs)-induced proximal tubular cell apoptosis and injury by reducing receptor for AGEs (RAGE) level. Metabolism, 2012, 61: 1067-1072. http://dx.doi.org/10.1016/j. metabol.2012.01.006

[67] MATSUI T, YAMAGISHI S, TAKEUCHI M, UEDA S, FUKAMI K, et al. Irbesartan inhibits advanced glycation end product (AGE)-induced proximal tubular cell injury in vitro by suppressing receptor for AGEs (RAGE) expression. Pharmacol Res, 2010, 61: 34-39. http://dx.doi.org/10.1016/j. phrs.2009.07.004

[68] YAMAGISHI S, NAKAMURA K, MATSUI T. Regulation of advanced glycation end product (AGE)-receptor (RAGE) system by PPAR-gamma agonists and its implication in cardiovascular disease. Pharmacol Res, 2009, 60: 174-178. http:// dx.doi.org/10.1016/j.phrs.2009.01.006

[69] HE X, ESTEVA FJ, ENSOR J, HORTOBAGYI GN, LEE MH, et al. Metformin and thiazolidinediones are associated with improved breast cancer-specific survival ofdiabetic women with HER2+ breast cancer. Ann Oncol, 2012, 23: 1771-1780. http://dx.doi.org/10.1093/annonc/mdr534

[70] ISHIBASHI Y, MATSUI T, TAKEUCHI M, YAMAGISHI S. Metformin inhibits advanced glycation end products (AGEs)- induced growth and VEGF expression in MCF-7 breast cancer cells by suppressing AGEs receptor expression via AMP-activated protein kinase. Horm Metab Res, 2013, 45: 387-390.

[71] LAM JK, WANG Y, SHIU SW, WONG Y, BETTERIDGE DJ, et al. Effect of insulin on the soluble receptor for advanced glycation end products (RAGE). Diabet Med, 2013, 30: 702-709. http://dx.doi.org/10.1111/dme.12166

[72] DE BITTENCOURT PASQUALI MA, GELAIN DP, ZEIDAN-CHULIA F, PIRES AS, GASPAROTTO J, et al. Vitamin A (retinol) downregulates the receptor for advanced glycation endproducts (RAGE) by oxidant-dependent activation of p38 MAPK and NF- $\kappa B$ in human lung cancer A549 cells.
Cell Signal, 2013, 25: 939-954. http://dx.doi.org/10.1016/j. cellsig.2013.01.013

[73] RAO NV, ARGYLE B, XU X, REYNOLDS PR, WALENGA $\mathrm{JM}$, et al. Low anticoagulant heparin targets multiple sites of inflammation, suppresses heparin-induced thrombocytopenia, and inhibits interaction of RAGE with its ligands. Am J Physiol Cell Physiol, 2010, 299: C97-C110. http://dx.doi. org/10.1152/ajpcell.00009.2010

[74] MIZUMOTO S, TAKAHASHI J, SUGAHARA K. Receptor for advanced glycation end products (RAGE) functions as receptor for specific sulfated glycosaminoglycans, and antiRAGE antibody or sulfated glycosaminoglycans delivered in vivo inhibit pulmonary metastasis of tumor cells. J Biol Chem, 2012, 287: 18985-94. http://dx.doi.org/10.1074/jbc. M111.313437

[75] NOGUEIRA-MACHADO JA, DE OLIVEIRA VOLPE CM. HMGB-1 as a target for inflammation controlling. Recent Pat Endocr Metab Immune Drug Discov, 2012, 6: 201-209. http:// dx.doi.org/10.2174/187221412802481784

[76] ARUMUGAM T, RAMACHANDRAN V, SUN D, PENG Z, PAL A, et al. Designing and developing S100P inhibitor 5-methyl cromolyn for pancreatic cancer therapy. Mol Cancer Ther, 2013, 12: 654-662. http://dx.doi.org/10.1158/1535-7163. MCT-12-0771

[77] ARUMUGAM T, RAMACHANDRAN V, GOMEZ SB, SCHMIDT AM, LOGSDON CD, et al. S100P-derived RAGE antagonistic peptide reduces tumor growth and metastasis. Clin Cancer Res, 2012, 18: 4356-4364. http://dx.doi. org/10.1158/1078-0432.CCR-12-0221

[78] YAMAGISHI S, MATSUI T. Soluble form of a receptor for advanced glycation endproducts as a biomarker. Front Biosci (Elite Ed.), 2010, 2: 1184-1195. http://dx.doi.org/10.2741/E178

[79] RADIA AM, YASER AM, MA X, ZHANG J, YANG C, et al. Specific siRNA targeting receptor for advanced glycation end products (RAGE) decreases proliferation in human breast cancer cell lines. Int J Mol Scil, 2013, 14: 7959-7978. http:// dx.doi.org/10.3390/ijms14047959 